Int. J. Morphol.,

27(3):719-725, 2009.

\title{
Altered Liver Morphology and Enzymes in Streptozotocin Induced Diabetic Rats
}

\author{
Morfología y Enzimas del Hígado Alteradas en Ratas con Diabetes Inducida por Estreptozotocina
}

"Muhammad Zafar; "**Syed Naeem-ul-Hassan Naqvi; "Masood Ahmed \& ${ }^{* * *}$ Zahid Ali Kaimkhani

ZAFAR, M.; NAEEM-UL-HASSAN NAQVI, S.; AHMED, M. \& KAIMKHANI, Z. A. Altered liver morphology and enzymes in streptozotocin induced diabetic rats. Int. J. Morphol., 27(3):719-725, 2009.

SUMMARY: This study was undertaken to evaluate the relationship and effects of diabetes on liver morphology, architecture and function. The hepatic effects of diabetes were evaluated in vivo using streptozotocin (STZ)-induced diabetic rats as an experimental model. The degree of hepatic dysfunction was measured by using biochemical parameters like serum transaminases (ALT and AST), alkaline phosphatase (ALP)and pseudocholinesterase (PChE) while the histopathological studies were carried out to support the enzymic Parameters. The aim of the study was to investigate the association between diabetic hepatic complications and liver enzyme alterations. This study was performed in the Department of Anatomy; Institute of Pharmaceutical Sciences and Institute of Diabetology and endocrinology of Baqai Medical University, Karachi. Diabetes was induced by a single dose of STZ (45 mg/kg, b.w.) given intraperitoneally in sodium citrate buffer at $\mathrm{pH}$ 4.5. Eighty albino rats were divided into five groups: control (A) and STZ treated (B, C, D, and E) which were sacrificed 2, 4, 6 and 8 weeks post treatment respectively. Histopathological examination of liver showed accumulation of lipid droplets, lymphocytic infiltration, increased fibrous content, dilatation and congestion of portal vessels and proliferation of bile ducts. Increased levels of aspartate aminotransferase (AST), alanine aminotransferase (ALT), ALP and PChE were observed in the liver. It seems that the diabetic complications in the liver like hepatocyte destruction etc. are likely to be due to alterations in enzyme levels.

injury.

KEY WORDS: Streptozotocin; Aminotransferases; Alkaline phosphatase; Pseudocholinesterase; STZ-diabetes; Hepatic

\section{INTRODUCTION}

Streptozotocin (STZ) is a naturally occurring nitrosourea with molecular weight of 265 and empirical formula of C14 H27 N5 O12 (Dorr \& Fritz, 1980). It is widely used to induce insulin-dependent diabetes mellitus in experimental animals because of its toxic effects on islet beta cells (Ohno et al., 2000; Merzouk et al., 2000). The diabetogenic action of STZ is the direct result of irreversible damage to the pancreatic beta cells resulting in degranulation and loss of capacity to secrete insulin (Magee $\&$ Swann, 1969). The effects of STZ on different organs have been extensively studied. STZ has various biological actions, including the production of acute and chronic cellular injury, carcinogenesis, teratogenesis and mutagenesis (Magee \& Swann). STZ is a nitrosourea compound which generally shares similar fate of disposition with other nitrosoureas and is a drug of choice in islet cell carcinoma and malignant carcinoid tumors. It is diabetogenic, hepatotoxic, nephrotoxic and also causes gastric ulceration (Piyachaturawat et al., 1988; Piyachaturawat et al., 1990). STZ given intravenously or intraperitoneally to laboratory mice in multiple subdiabetogenic doses, induces pronounced pancreatic insulitis with eventual destruction of insulin-secreting beta cells and diabetes mellitus. In an experimental study in rats, STZ injected in a dose of $65 \mathrm{mg} / \mathrm{kg}$ body weight effectively produced hyperglycemia and gastric mucosal ulcerations (Piyachaturawat et al., 1988; Piyachaturawat et al., 1990). The incidence and severity of lesions produced by STZ in pancreas, liver, kidney and GIT, progressively increased with time from one to six weeks post treatment (Piyachaturawat et al., 1988). Similarly, many studies have shown an association between specific diabetic complications and disturbances in various tissues, such as diabetic nephropathy

\footnotetext{
* Department of Anatomy, Baqai Medical University, Karachi, Pakistan

** Institute of Pharmaceutical Sciences, Baqai Medical University, Karachi, Pakistan

**** Department of anatomy, King Saud University, Riyadh, Saudi Arabia
} 
and peripheral neuropathy, but only limited data is available on the possible association between diabetic complication and liver functions (Gu et al., 1997; Arkkila et al., 2001).

\section{MATERIAL AND METHOD}

This study was performed in the Department of Anatomy, Institute of Pharmaceutical Sciences and Institute of Diabetology and Endocrinology of Baqai Medical University. STZ was obtained in powder form from Sigma Chemical Company, St. Louis, USA.

Immediately before use, STZ was dissolved in $10 \mathrm{mM}$ sodium citrate buffer, $\mathrm{pH} 4-4.5$, made isotonic by the addition of an appropriate volume of $0.25 \mathrm{M} \mathrm{NaCl}$ (Bennett \& Pegg, 1981). After takingapproval from the ethical committee, a total of 80 adult male albino rats (body weight 100-200 gm) of Charles River strian were obtained from Jinnah Postgraduate Medical Center (J.P.MC). This strain was originally obtained from Charles River Breeding Laboratories Brooklyn, Massachussets, USA. All rats were housed in metabolic cages on a 12-h light/dark cycle at a temperature of $22-24^{\circ} \mathrm{C}$ (Petlevski et al., 2006). The animals were divided into five groups; A, B, C, D, and E. There were 40 animals in group ' $A$ ' while groups B, C, D, and E each comprising of 10 animals. The group 'A' was control and groups B, C, D, and E were treated with STZ. After an overnight fast, the animals of groups B, C, D, and E were injected with a single dose of STZ (45 mg/kg, b.w.) intraperitoneally in sodium citrate buffer at $\mathrm{pH} 4.5$ (Ramesh \& Pugalendi, 2006; Gayathri \& Kannabiran, 2008). After the administration of STZ, the animals were given $1 \%$ sucrose solution to prevent hypoglycemia. Plasma glucose was estimated before the administration of STZ, after 24 hours and at the end of $2^{\text {nd }}, 4^{\text {th }}, 8^{\text {th }}$ and $12^{\text {th }}$ weeks by taking blood samples from the tail vein (Chaude et al., 2001). Animals in group ' $\mathrm{A}$ ' (control) were administered sodium citrate buffer $\mathrm{pH} 4.5$ in a dose of $0.2 \mathrm{ml} / 100$ grams body weight, intraperitoneally. After an overnight fast, the animals of group B, C, D and E were sacrificed at the end of $2 \mathrm{nd}, 4^{\text {th }}$, $8^{\text {th }}$ and $12^{\text {th }}$ weeks respectively while ten animals from the control group were sacrificed at the end of $2^{\text {nd }}, 4^{\text {th }}, 8^{\text {th }}$ and $12^{\text {th }}$ weeks respectively. The livers were identified and observed for any gross appearance and color change with magnifying glass and tissues were preserved for histopathological studies and enzymatic estimation. For histopathology, the liver tissues were immediately transferred to $10 \%$ formal saline for paraffin embedding and staining with Hematoxylin \& Eosin (H\&E), Periodic Acid-Schiff (PAS) and Masson's trichrome stains. For enzyme estimation, livers were immediately excised, washed in ice-cold saline, blotted on tissue paper and immediately transferred to phosphate buffer ( $\mathrm{pH}$ 7.4) for preservation. Liver tissues were homogenized $(100 \mathrm{~g} \mathrm{~L}-1)$ in cold $(0.14 \mathrm{~mol} \mathrm{~L} \mathrm{-1)} \mathrm{KCl} \mathrm{using}$ a Teflon homogenizer (Measuring \& Scientific Equipment, UK). Homogenates were centrifuged in labofuge 15000 centrifuge at temperature $4^{\circ} \mathrm{C}$ and $5000 \mathrm{rpm}$ for 20 minutes, placed in cold chambers. Supernatants were stored at $-20^{\circ} \mathrm{C}$ until analysis (Petlevski et al., 2002). GOT and GPT activities were determined by the colorimetric method using Randox Diagnostic No. 146 kit. Activity of ALP was determined spectrophotometrically by AMP method using Roche diagnostic kit 396460. Whereas, PChE activity was determined by the colorimetric method using a commercial kit no. CE190.

Data are shown as means \pm S.E.M. The statistical significance of the changes in enzyme levels of control and STZ treated animals were evaluated by using the one-way ANOVA test of variance. The difference in enzyme levels was regarded as statistically significant if the ( $\mathrm{P}$ value was $<$ 0.05) F-value was greater and was regarded as statistically non-significant if the F-value was lesser. Sigma Stat program for Windows, (Jandel Corporation, USA), was used for statistical analysis.

\section{RESULTS}

The gross examination of liver showed yellowish brown discoloration in livers taken from animals in groups B, C, D and E.

Sections of liver from group 'B' showed congestion in portal vessels \& sinusoids with mild centrilobular hepatocyte degeneration. Sections of liver from group ' $C$ ' showed in addition a mild lymphoplasmacytic infiltration in the portal tracts with destruction of some bile ducts. Destructive changes were more obvious in the animals of group ' $D$ ' and ' $E$ '. There was loss of usual concentric arrangement of hepatocytes and portal vessels and the sinusoids were congested. There was an inflammatory infiltrate in the portal tract (Fig. 4) which caused destruction of the smaller (interlobular and septal) intrahepatic bile ducts in group- 'E'. The inflammatory infiltrate varied in intensity from one tract to other. There appeared a proliferation of bile ducts in the portal tracts in group- 'E' (Fig. 5). Some of the sections showed dilatation of veins. Glycogen content in many of the hepatocytes in group-'E' was much decreased. There was an accumulation of lipiddroplets in the cytoplasm of hepatocytes (Fig. 3).

Tables I and II show the enzyme activities in control 


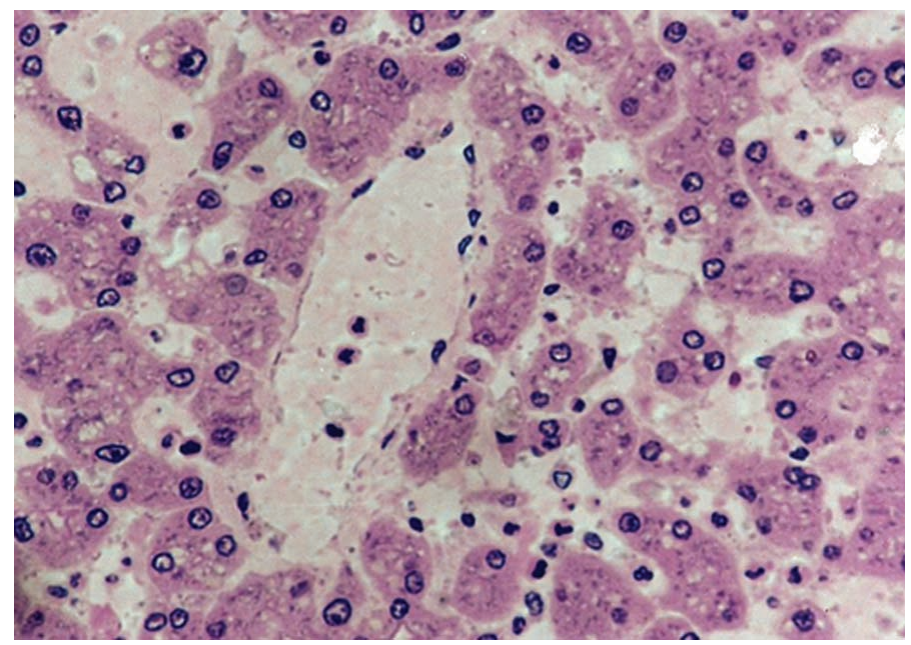

Fig. 1. Photomicrograph of 3 microns thick $\mathrm{H} \& \mathrm{E}$ stained paraffin section from the liver of a normal rat (group-A) showing normal lobular pattern with a centrilobular vein and radiating irregular anastomosing plates of hepatocytes with intervening sinusoids

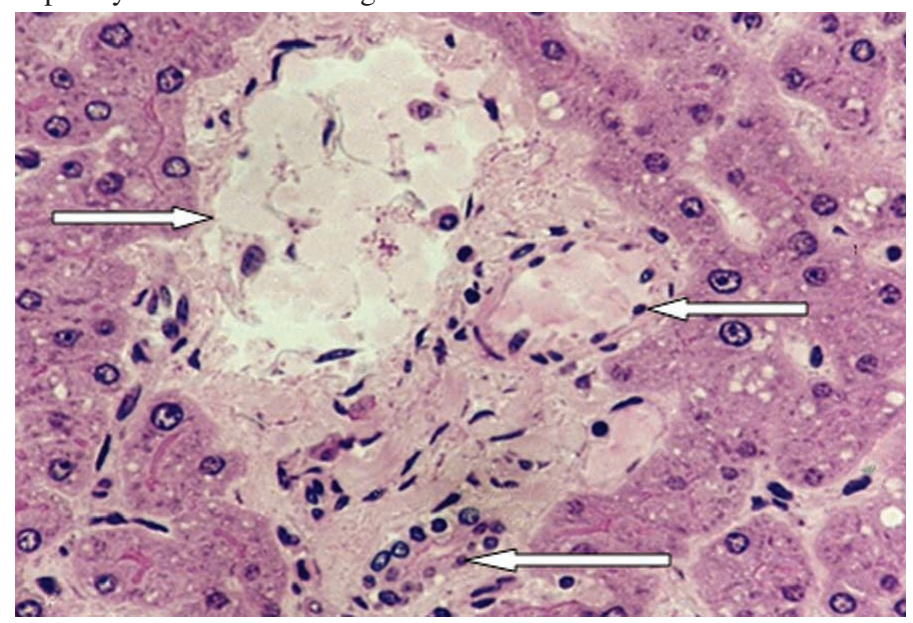

Fig. 2. Photomicrograph of 3 microns thick $H$ \& E stained paraffin section from the liver of a normal rat (group-A) showing a portal triad consisting of a branch of portal vein, hepatic artery and bile duct ? 400 .

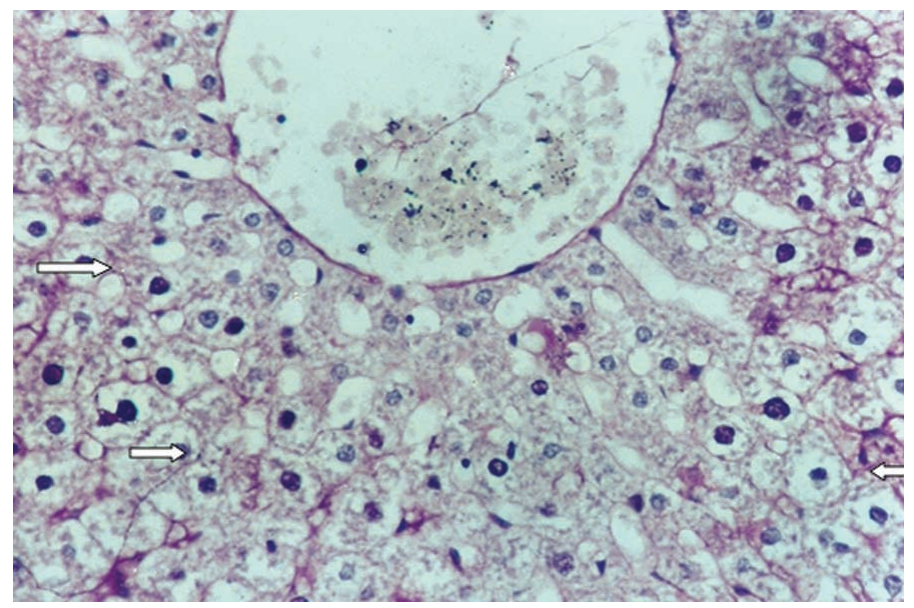

Fig. 3. Photomicrograph of 3 microns thick PAS stained paraffin section from the liver in a streptozotocin treated rat (group-E) showing accumulation of lipid droplets (Arrows). X 400. and STZ-induced diabetes in rats. The mean values of the levels of AST, ALT, ALP and PChE were $13.7 \pm$ $2.26 \mathrm{IU} / \mathrm{L}, 21.2 \pm 2.15 \mathrm{IU} / \mathrm{L}, 72.2 \pm 2.52 \mathrm{IU} / \mathrm{L}$ and $5084.00 \pm 395.6 \mathrm{IU} / \mathrm{L}$ in group 'A' respectively. This study showed an increase in the levels of AST, ALT, ALP and PChE in the liver in groups B, C, D, and E when compared with the control group (Table I). A significant increase $(\mathrm{P}<0.04)$ in the AST levels, a significant increase $(\mathrm{P}<0.055)$ in the ALT levels, a significant increase $(\mathrm{P}<0.001)$ in the ALP levels and a significant increase $(\mathrm{P}<0.008)$ in the $\mathrm{PChE}$ levels were observed when treated groups B, C, D, and E were compared with group A (Table II).

\section{DISCUSSION}

Several workers have reported that STZ-induced diabetes mellitus and insulin deficiency lead to increased blood glucose (Saeed et al., 2008) and association between specific diabetic complications and disturbances in various tissues, such as diabetic nephropathy and cardiovascular diseases, but only limited data is available on the possible association between diabetic complications and liver function (Arkkila et al.). The present study was designed to observe the effects of STZ-induced diabetes on the liver and liver enzymes at various time intervals after STZ treatment. Elevated activities of serum aminotransferases are a common sign of liver diseases and are observed more frequently among people with diabetes than in general population (Arkkila et al.; Bennett \& Pegg).

In present study, a yellowish brown color of the liver was observed which could be due to the fatty liver formation. Fatty liver and hyperlipidemia in IDDM of streptozotocin-induced treated shrews were also reported by Ohno et al. In our study, the histopathology of liver showed a progressive development of the lesions which seems to be due to STZ. Most liver sections showed increased fibrosis with plasmacytic infiltrate causing distortion of usual concentric arrangement of hepatocytes. There was also congestion of portal vessels and sinusoids and the veins were also dilated. These findings of present study are in agreement with the findings of Das et al. (1996) and Degirmenchi et al. (2002) who showed dilatation of veins, loss of usual concentric arrangement of hepatocytes, liver fibrosis and decreased in glycogen activity in their study. 


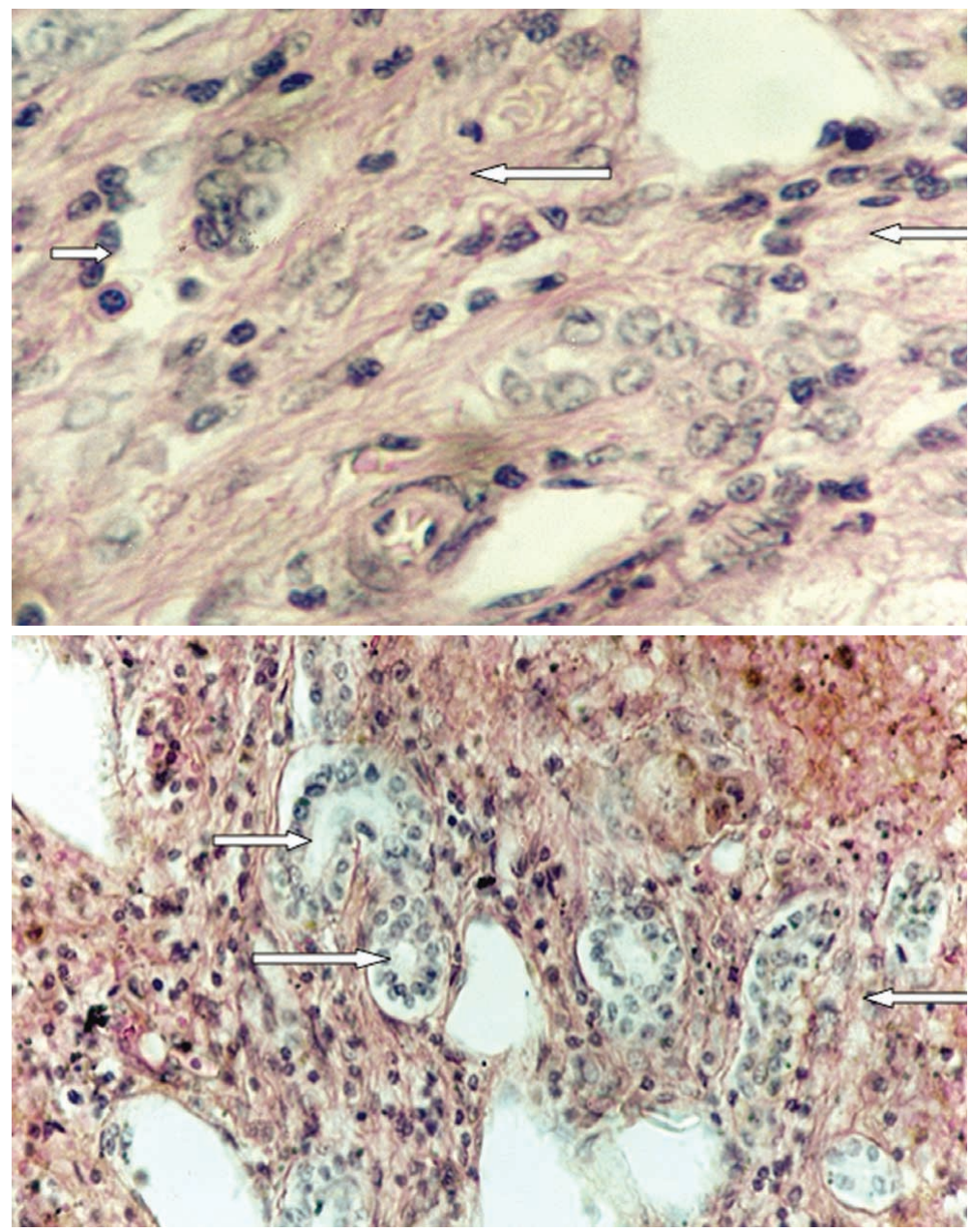

Fig. 4. Photomicrograph of 3 microns thick H \& E stained paraffin section from the liver in a streptozotocin treated rat (group-E) showing lymphocytic infiltration and increased fibrous content in the portal tract. (Arrows) ? 400.

Fig. 5. Photomicrograph of 3 microns thick H \& E stained paraffin section from the liver in a streptozotocin treated rat (group-E) showing proliferation of bile ductules (Arrows). ? 400.

Table I. Effects of streptozotocin-induced diabetes on the activity of liver enzymes in albino rats. Results are expressed as means + SEM for control and STZ-treated rats. Ten animals were used in each group.

\begin{tabular}{ccccccc}
\hline Enzymes (IU/L) & Group-A & Group-B & Group-C & Group-D & Group-E & P-Value \\
\hline AST & $13.7 \pm 2.26$ & $416.8 \pm 110.31$ & $415.8 \pm 98.78$ & $388.1 \pm 108.29$ & $434.4 \pm 123.7$ & P $<0.04$ \\
ALT & $21.2 \pm 2.15$ & $518.9 \pm 149.2$ & $560.00 \pm 136.99$ & $546.7 \pm 121.58$ & $542.7 \pm 136.33$ & P $<0.055$ \\
ALP & $72.2 \pm 2.52$ & $773.7 \pm 159.36$ & $756.7 \pm 155.1$ & $866.00 \pm 113.98$ & $735.9 \pm 113.85$ & P $<0.001$ \\
PchE & $5084.00 \pm 395.6$ & $7928.5 \pm 856.25$ & $7486.8 \pm 913.38$ & $9165.2 \pm 688.55$ & $9035.8 \pm 85.06$ & P $<0.008$ \\
\hline
\end{tabular}

Table II. Statistical analysis of the difference in mean levels of AST, ALT, ALP and PchE in liver between groups A, B, $\mathrm{C}, \mathrm{D}$ and $\mathrm{E}$ in albino rats. Key: $\mathrm{F}=$ Treatment level i.e. Groups $\mathrm{A}-\mathrm{E}$.

\begin{tabular}{ccccc}
$\begin{array}{c}\text { es (Enzymes) } \\
\text { AST }\end{array}$ & $\begin{array}{c}\text { F-Values } \\
\mathrm{F}=4.16\end{array}$ & $\begin{array}{c}\text { P-Values } \\
\mathrm{P}<0.04\end{array}$ & $\begin{array}{c}\text { Degree of freedom (d.f.) } \\
4.8\end{array}$ & $\begin{array}{c}\text { Conclusion } \\
\text { AST is significantly } \\
\text { different (increased) in } \\
\text { groups A - E } \\
\text { ALT is significantly } \\
\text { different (increased) in } \\
\text { groups A - E }\end{array}$ \\
ALP & $\mathrm{F}=3.69$ & $\mathrm{P}<0.055$ & 4.8 & $\begin{array}{c}\text { ALP is significantly } \\
\text { different (increased) in } \\
\text { groups A - E }\end{array}$ \\
PChE & $\mathrm{F}=14.96$ & $\mathrm{P}<0.001$ & 4.8 & $\begin{array}{c}\text { PChE is significantly } \\
\text { different (increased) in } \\
\text { groups A - E }\end{array}$ \\
\hline
\end{tabular}


We observed accumulation of lipid droplets in the cytoplasm of hepatocytes. This change was reminiscent to the formation of fatty liver. It could be due to the increased influx of fatty acids into the liver induced by hypoinsulinemia and the low capacity of excretion of lipoprotein secretion from liver resulting from a deficiency of apolipoprotein B synthesis (Ohno et al.) Hyperlipidemia could be another factor for fatty liver formation. Our findings of fatty liver formation are in agreement with the findings of (Ohno et al.; Merzouk et al.). The glycogen content of the hepatocytes in the liver of STZ-treated animals was markedly decreased (Thulesen et al., 1997; Das et al.). It could be due to the displacement of glycogen in the cytoplasm of hepatocytes as a consequence of accumulation of lipid droplets (Thulesen et al.). Our study showed that the aminotransferases (AST and ALT) levels were significantly increased in the liver of STZ-treated animals as shown in table-I. Serum ALT, AST and ALP levels were determined to evaluate the hepatic functions (Degirmenchi et al.). The increase in aminotransferases levels may be due to the cellular damage in the liver caused by STZ-induced diabetes. Although ALT is also present in mitochondria and cytosol, the mitochondrial form is low in activity and is very unstable. The detailed mechanism by which enzymes are released from the cytosol and mitochondria of hepatocytes is not completely known. Experimental studies have shown that subtle membrane changes are sufficient to allow passage of intracellular enzymes to the extracellular space (Garella, 1997).Very large concentration gradient between the hepatocytes and the sinusoidal space usually exists for enzymes. Cell damage increases permeability causing cytosolic isoenzymes to spill into the sinusoids and from there into the peripheral blood (Garella). Baxter \& Schofield reported an increase in AST and ALT in diabetics. It had been shown by Rogers et al. (1986), that mitochondrial activity was decreased $53 \%$ per gram of diabetic liver and cytoplasmic AST activity was increased 3-4 fold in STZ diabetic rats. Voss et al. (1988) proposed that STZ in hyperglycemic animals caused a time dependent rise in AST, ALT, and ALP levels. The work of Barneo et al. (1990) showed that STZ induced diabetes in rats produced alterations in hepatic functions as described in poorly controlled diabetics. This alteration in hepatic function may be because of increase activity and mRNA levels of araginase as reported by Salimuddin et al. (2008) in their study. Hepatocellular dysfunction was evaluated by the AST and ALT activities in plasma. The results of our study showed that STZ diabetes in rats produced alterations in the hepatic functions as well as structure of hepatocytes. The increase in the levels of AST and ALT in diabetic rats after 1-3 weeks treatment was also reported by many other workers (Zhang et al., 1995; Isogai et al., 1997). Okada et al. (1997) reported that AST activity was lower than the amount of enzyme in diabetic rat tissues. It is suggested that this may be due to the inactivation of cytosolic AST in the diabetic rat tissues by a glycation reaction, accompanied by impairment in glucose utilization in STZ induced diabetes.

In our study, the levels of ALP were significantly increased in the liver of treated animals as shown in Table I and II. The mechanism of release of membrane bound enzyme is less well understood. Alkaline phosphatase is a membrane bound glycoprotein enzyme. It is present in highest concentrations in the sinusoids and in the endothelium of the central and periportal veins; smaller concentrations occur in the biliary canaliculi. Barneo et al. evaluated cholestasis by plasma ALP activity in STZ induced diabetes and their results showed that ALP levels were raised. Leibovitch et al. (1991) observed increased levels of serum ALP in pathological conditions involving the kidneys and liver. Increase in the levels of ALP in diabetic rats was also reported by Ramesh \& Pugalendi. Pseudocholinesterase levels in serum are useful as test of liver functions. In the present study, the levels of PChE in the liver of treated animals were found to be significantly increased as shown in the Table I. Song et al. (1996) reported increased serum cholinesterase with increase triglyceride levels in diabetics. They pointed out a possible association between increased serum cholinesterase and vascular complications. Other researchers reported a significant increase in cholinesterase activity in STZ induced diabetes (Abbot et al., 1993; Kutty \& Payne, 1994). Cholinesterase might have a role in altered lipoprotein metabolism in hypertriglyceridaemia associated with insulin deficiency in diabetes mellitus.

This study shows that STZ-induced diabetes and hypoinsulinemia, results in various pathologic lesions seen in the liver. It also alters various metabolic and enzymatic functions of liver. It may also be concluded that the diabetic complication in the liver may be attributed to alterations in the liver enzyme levels. The STZ through its direct alkylating action can cause cellular necrosis and selective destruction of pancreatic beta cells producing hyperglycemia at a dose of $45 \mathrm{mg} / \mathrm{kg}$ body weight.

ZAFAR, M.; NAEEM-UL-HASSAN NAQVI, S.; AHMED, M. \& KAIMKHANI, Z. A. Morfología y enzimas del hígado alteradas en ratas con diabetes inducida por estreptozotocina. Int. J. Morphol., 27(3):719-725, 2009.

RESUMEN: Este estudio se realizó para evaluar la relación y los efectos de la diabetes sobre la morfología, arquitectura y la función del hígado. Los efectos hepáticos de la diabetes se evaluaron in vivo utilizando estreptozotocina (STZ) para inducir diabetes en ratas como un modelo experimental. El grado de disfunción hepática se midió mediante el uso de parámetros bioquímicos, como las transaminasas séricas (ALT y AST), fosfatasa alcalina (ALP) y 
pseudocolinesterasa (PChE), mientras que los estudios histopatológicos se llevaron a cabo para apoyar los parámetros enzimáticos. El objetivo del estudio fue investigar la asociación entre las complicaciones hepáticas diabéticas y la alteración de enzimas hepáticas. Este estudio se realizó en el Departamento de Anatomía, Instituto de Ciencias Farmacéuticas y el Instituto de Diabetología y Endocrinología de la Baqai Medical University, Karachi. La diabetes fue inducida por una dosis única de STZ (45 $\mathrm{mg} / \mathrm{kg}$ de peso corporal) administrada por vía intraperitoneal en tampón citrato de sodio a pH 4,5. Ochenta ratas albinas se dividieron en cinco grupos: control (A) y tratados con STZ (B, C, D y E), las que se sacrificaron a las 2, 4, 6 y 8 semanas después del tratamiento. El examen histopatológico de hígado mostró acumulación de gotitas de lípidos, infiltración linfocítica, aumento del contenido de fibras, dilatación y congestión de los vasos portales, y la proliferación de conductos biliares. Aumento de los niveles de aspartato aminotransferasa (AST), alanina aminotransferasa (ALT), ALP y PChE fueron observados en el hígado. Parece que las complicaciones de la diabetes en el hígado como la destrucción de los hepatocitos etc., son probablemente debido a alteraciones en los niveles de las enzimas.

PALABRAS CLAVE: Estreptozotocina; Aminotransferasas; Fosfatasa alcalina; Pseudocolinesterasa; STZdiabetes; Lesión hepática.

\section{REFERENCES}

Abbott, C. A.; Mackness, M. I.; Kumar, S.; Olukoga, A. O.; Gordon, C.; Arrol, S.; Bhatnagar, D.; Boulton, A. J. \& Durrington, P. N. Relationship between serum butyrylcholinesterase activity, hypertriglyceridaemia and ninsulin sensivity in diabetes mellitus. Clin. Sci., 85(1):77-81, 1993.

Arkkila, P. E.; Koskinen, P. J.; Kantola, I. M.; Ronnemaa, T.; Seppanen, E. \& Viikari, J. S. Diabetic complications are associated with liver enzyme activities in people with type-1 diabetes. Diabetes Res. Clin. Pract., 52(2):1138,2001 .

Barneo, L.; Esteban, M. M.; Garcia-Pravia, C.; Diaz, F. \& Marin, B. Normalization of altered liver function tests after islet transplantation in diabetic rats. Diabete. Metab., 16(4):284-9, 1990.

Baxter, L. C. \& Schofield, P. J. The effects of a high fat diet on chronic Streptozotocin diabetic rats. Diabetologia, 18(3):239-54, 1980.

Bennett, R. A. \& Pegg, A. E. Alkylation of DNA in rat tissues following administration of Streptozotocin. Can. Res., 41:2786-90, 1981.
Chaude, M. A.; Orisakwe, O. E.; Afonne, O. J.; Gamenial, K. S.; Vongtau, O. H. \& Obi, E. Hypoglycemic effect of the aqueous extract of Boerrhavia diffusa leaves. Indian J. Pharmacol., 33:215-6, 2001.

Das, A. V.; Padayatti, P. S. \& Paulose, C. S. Effect of leaf extract of Aegle Marmelose (L.) Correa ex Roxb. On histological and ultrastructural changes in tissues of Streptozotocin induced diabetic rats. Indian J. Exp. Biol., 34(4):341-5, 1996.

Degirmenchi, I.; Kalender, S.; Ustuner, M. C.; Kalender, Y.; Gunes, H. V.; Unal, N. \& Basaran, A. The effects of acarbose and Rumex patientia on liver ultrastructure in streptozotocin-induced diabetic (type-II) rats. Drugs Exp. Clin. Res., 28:229-34, 2002.

Dorr, R. T. \& Fritz, W. L. Cancer chemotherapy. London, Kinapton, 1980. pp.632-7.

Garella, S. The cost of dialysis in the USA. Nephrol. Dial. Transplant., 12:10-2, 1997.

Gayathri, M.; Kannabiran, K. Hypoglycemic activity of Hemidesmus indicus R. Br. on streptozotocin-induced diabetic rats. Int. J. Diab. Dev. Ctries., 28:6-10, 2008.

Gu, D.; Arnush, M. \& Sarvetnic, N. Endocrine/exocrine intermediate cells in Streptozotocin treated Ins-IFNgamma transgenic mice. Pancreas, 15(3):246-50, 1997.

Isogai, M.; Kurota, H. \& Yamaguchi, M. Hepatic calcium binding protein regucalcin concentration is decreased by Streptozotocin diabetic state and ethanol injection in rats. Mol. Cell Biochem., 168(1-2):67-72, 1997.

Kutty, K. M. \& Payne, R. H. Serum pseudocholinesterase and very-low-density lipoprotein metabolism. J. Clin. Lab. Anal., 8(4):247-5, 1994.

Leibovitch, I.; Ben-Chaim, J.; Ramon, J. \& Goldwasser, B. B. Increase serum alkaline phosphatase activity: a possible indicator of renal damage. J. Clin. Lab. Anal., 5(6):406-9, 1991.

Magee, P. N. \& Swann, P. F. Nitroso compounds. Br. Med. Bull., 25:240-4, 1969.

Merzouk, H.; Madani, S.; Chabane, S. D.; Prost, J.; Bouchenak, M. \& Belleville, J. Time course of changes in serum glucose, insulin, lipids and tissue lipase activities in macrosomic offspring of rats with Streptozotocin induced diabetes. Clin. Sci., 98(1):21-30, 2000. 
Ohno, T.; Horio, F.; Tanaka, S.; Terada, M.; Namikawa, T. \& Kitch, J. Fatty liver and hyperlipidemia in IDDM (insulin dependent diabetes mellitus) of Streptozotocin treated shrews. Life Sci., 66(2):125-31, 2000.

Okada, M.; Murakami, Y. \& Miyomoto, E. Glycation and inactivation of aspartate aminotransferase in diabetic rat tissues. J. Nutr. Sci. Vitaminol., 43(4):463-9, 1997.

Petlevski, R.; Hadzija, M.; Bajalo, J. L. \& Juretic, D. Effects of acarbose on alanine aminotransferase and aspartate aminotransferase activities in the liver of control and diabetic CBA mice. Acta. Pharma., 56:8793, 2006.

Petlevski, R.; Juretic, D.; Mayer, Lj.; Hadzija, M.; Slijepcevic, M. \& Lukac-Bajalo, J. Effect of acarbose on glucose-6-phosphatase in liver of CBA diabetic mice. Period. Biol., 104:73-5, 2002.

Piyachaturawat, P.; Poprasit, J. \& Glinsukon, T. Gastric mucosal secretions and lesions by different doses of Streptozotocin in rats. Toxicol. Let., 55:21-9, 1990.

Piyachaturawat, P.; Poprasit, J.; Glinsukon, T. \& Warichanon, C. Gastric mucosal lesions in Streptozotocin diabetic rats. Cell Biol. Intern. Rep., 12(1):53-63, 1988.

Ramesh, B. \& Pugalendi, K. V. Impact of umbelliferone (7hydroxycourmarin) on hepatic marker enzymes in Streptozotocin diabetic rats. Indian J. Pharmacol., 38:209-10, 2006.

Rogers, K. S.; Higgins, E. S. \& Kline, E. S. Experimental diabetes causes mitochondrial loss and cytoplasmic enrichment of pyridoxal phosphate and aspartate aminotransferase activity. Biochem. Med. Metab. Biol., 36(1):91-7, 1986.

Salimuddin; Upadhyaya, K. C.; Baquer, N. Z. Effects of vanadate on expression of liver araginase in experimental diabetic rats. IUBMB Life, 48(2):237-40, 2008.

Saeed, M. K.; Deng, Y. \& Dai, R. Attenuation of Biochemical Parameters in Streptozotocin-induced Diabetic Rat by Oral Administration of Extracts and Fractions of Cephalotaxus sinensis. J. Clin. Biochem. Nutr., 42:218, 2008.

Song, R. H.; Singh, A. K. \& Leehey, D. J. Decreased glomerular proteinase activity in the STZ- diabetic rats. Am. J. Nephrol., 19(3):441-6, 1996.
Thulesen, J.; Orskov, C.; Holst, J. J. \& Poulsen, S. S. Shortterm insulin treatment prevents the diabetogenic action of streptozotocin in rats. Endocrinology, 138(1):62-8, 1997.

Voss, C.; Brachmann, K. \& Hartmann, K. Effect of Streptozotocin on transaminases, creatinine and urea in serum of rats. Exp. Clin. Endocrinol., 92(1):37-42, 1988.

Zhang, A.; Vetromenn, J.; Van Gaal, L. \& De Leeuw, I. Effects of pravastatin on lipid levels in vitro oxidizability of non-HDL lipoproteins and microalbuminuria in IDDM patients. Diabetes Res. Clin. Pract., 29(3):189-94, 1995.

Correspondence to:

Prof. Dr. Muhammad Zafar

Department of Anatomy, Faculty of Medicine

King Fahad Medical City, Riyadh

PO Box 50946, 11525

SAUDI ARABIA

Tel.:00966-1-2935238

00966-1-2889999 (ext. 5981)

00966-561287496

Email: mzafer@kfmc.med.sa shaikhm_63@hotmail.com

Received: 06-01-2009

Accepted: 15-04-2009 
